\title{
Lobbies alimentares
}

\section{Food lobbies}

\section{Elaine de Azevedo ${ }^{1}$}

RESUMO: Este estudo conceitual se debruça sobre lobbies alimentares - atividades políticas legais designadas para influenciar o congresso, as agências federais e o governo, propondo leis que beneficiem as companhias alimentares e os grupos de commodities agrícolas em detrimento dos interesses e das preocupações da saúde coletiva. O tema, central na pesquisa de Marion Nestle desde a década de 1990, é essencial para discutir a construção social do conceito de alimento saudável sob a ótica do neoliberalismo. No entanto, nenhuma de suas publicações foi ainda traduzida para a língua portuguesa. O artigo mobiliza jornalistas e autores das áreas de Ciências Social e Política e oferece um estímulo para futuras pesquisas nessa área de conhecimento, sem a pretensão de abarcar o amplo alcance das publicações de Marion Nestle.

Palavras-chave: lobbies alimentares; alimento saudável; poder.
ABSTRACT: This conceptual study focuses on food lobbies - legal political activities designed to influence Congress, federal agencies and the government by proposing laws that benefit food companies and agricultural commodity groups to the detriment of collective health concerns and concerns. The theme, central to Marion Nestle's research since the 1990s, is essential to discuss the social construction of the concept of healthy food from the standpoint of neoliberalism. However, none of her publications have been translated into Portuguese. The article mobilizes journalists and authors of the Political and Social Sciences areas and offers a stimulus for future research in this area of knowledge, without claiming to encompass the wide reach of Marion Nestle's publications.

Keywords: food lobbies; healthy food; power.

1 Doutora em Sociologia Política pela Universidade Federal de Santa Catarina, professora do Departamento de Ciências Sociais da Universidade Federal do Espírito Santo, com pesquisa na área de sociologia da alimentação, saúde e meio ambiente. 


\section{Introdução}

Não é um conhecimento novo que a indústria alimentar influencia o que comemos e, como consequência disso, interfere nas decisões e nos conselhos de especialistas em saúde coletiva e na nossa saúde. As questões éticas que envolvem tal fato são bastante complexas, mas as empresas alimentares não são agências que prestam serviço público e não assumem nenhum tipo de comprometimento com a promoção da saúde. Seu foco é o lucro. A interferência das indústrias alimentares nas políticas de alimentação e nutrição chama-se "lobby alimentar" e é um tema ainda pouco estudado no âmbito da academia no Brasil.

As práticas de lobbies, amplamente discutidas pela nutricionista estadunidense Marion Nestle em pelo menos duas publicações-Food politics (2002) e Unsavory truth: how food companiesskew the science of what we eat (2018) -, são atividades políticas legais, não consideradas ações de suborno, designadas para influenciar o congresso, as agências federais e o governo, no sentido de proporem leis que beneficiem as companhias alimentares e os grupos de commodities agrícolas. Os lobistas oferecem conselhos técnicos apoiados pela pesquisa científica e propõem legislação, regulação e práticas de educação, sem serem, entretanto, legal mente eleitos pelo voto dos cidadãos. Na verdade, os lobistas são contratados pelas empresas para fazer essa negociação. Outros métodos de lobistas incluem contatos pessoais estabelecidos em ocasiões sociais, contribuições para campanhas políticas, organização de eventos de mídia e de demonstrações públicas, apoio financeiro à pesquisa acadêmica na área da alimentação, bem como suporte a periódicos, suplementos científicos e grupos de aconselhamento sobre nutrição e saúde, congressos e conferências.

Araújo (2018) apresenta uma definição mais condescendente na qual associa o lobby à legitimidade democrática: um esforço deliberado, que faz parte de um processo inerente à democracia, para promover, defender ou representar qualquer interesse particular ou de terceiros e, a partir desse interesse, influenciar a tomada de decisões administrativas ou legislativas em determinado sentido.

Interessam, neste estudo, a crítica negativa e os efeitos dos lobbies alimentares sobre a saúde coletiva que reverbera dentro da teoria de regulação econômica' em Stigler, que postula: "via de regra, a regulação é adquirida pela indústria, sendo elaborada e implementada para beneficiála" (Stigler, 1975, apud Baird, 2016, p. 69). Já em 1993, Marion Nestle chamou atenção para a reação dos lobistas da indústria de carne e laticínios que pressionaram o Departamento de Agricultura dos Estados Unidos, quando este assumiu uma orientação dos especialistas em nutrição relacionada à diminuição do consumo de proteína animal (na forma da Pirâmide Alimentar). Em 1998,

Para Baird (2016, p. 16), a teoria de regulação econômica "postula um sistema por meio do qual as indústrias demandariam regulação e os políticos, por sua vez, ofertariam essa regulação. A relação funcionaria da seguinte forma: os partidos políticos têm altos custos de operação para manter a máquina partidária funcionando, de modo que necessitam de dois tipos de recursos: auxílio financeiro e votos. As indústrias, por sua vez, necessitam da regulação para obter benefícios advindos do governo. A partir dessa relação de oferta e demanda, estrutura-se um sistema em que as indústrias financiam os políticos, garantindo sua sobrevivência, enquanto estes, em troca, disponibilizam a regulação econômica, assegurando toda sorte de benefícios às empresas". 
a então secretária de saúde do governo Clinton, Donna Shalala, foi utilizada como "garota propaganda" da National Fluid Milk Processor Promotion Board e apareceu no jornal The New York Times sorridente e com marca de leite sobre o lábio superior, fazendo apologia ao uso dos laticínios para manter a saúde e prevenir osteoporose com a chamada “leite: onde está o seu bigode?". Esta foi uma das muitas tentativas da indústria para influenciar as recomendações dietéticas federais e uma das primeiras pesquisas e alertas nesse campo realizada no âmbito acadêmico (Nestle, 1993; 2002).

\section{Lobbies: ponderações históricas}

O objetivo deste artigo não é oferecer um contexto histórico do lobby, uma vez que autores como Gonçalves (2012) e Santos et al. (2017) alcançam tal objetivo. Mesmo assim, um breve olhar será aqui oferecido.

A longa tradição de aceitação dos lobbies é parte integral do sistema político estadunidense, considerado a meca dos lobistas.

A prática de pressão de alguns grupos junto aos parlamentares surgiu na Inglaterra e é conhecida desde o século XIV. Em 1787, James Madison, quarto presidente dos Estados Unidos, mencionou o perigo do que chamou "vício das facções", como um resultado inevitável da natureza humana e de sociedades com distribuição desigual de propriedades. Nestle (2002) menciona que Madison acreditava que as "travessuras" causadas pelo interesse de alguns grupos específicos seriam, gradativamente, controladas por regras maioritárias. Ou seja, a violência dos lobbies seria desmascarada pela constituição de quem Madison é considerado o mentor. De fato, nos Estados Unidos, pelos 150 anos seguintes, o Congresso tentou, sem sucesso, controlar os abusos dos lobistas. Em 1959, cedeu às pressões e tornou a prática legal, assumindo a ineficácia frente à tentativa de seu controle. Em 1995, foi aprovada uma lei - Lobbying Disclosure Act - que definia lobista como um indivíduo que usava pelo menos $20 \%$ do seu tempo exercendo essa atividade, que tinha contatos com órgãos e grupos governamentais e que recebia mais de cinco mil dólares por seis meses de trabalho como lobista. Pessoas que não seenquadravam nos três quesitos não precisavam se registrar como lobista. Outras regras foram definidas com relação ao ganho de presentes, benefícios como viagens, refeições, presentes e eventos de lazer, mas tais restrições foram extintas posteriormente e permitiram a formação do que Nestle chama de uma indústria de lobbies.

Para Santos et al. (2017), há pouca informação sobre a comunidade de lobby que atua no sistema político brasileiro diante da inexistência de um levantamento de organizações e profissionais dedicados à regulamentação dos lobistas. Tal dificuldade também se verifica em países que já regulamentaram a atividade e que preveem o cadastramento como condição para atuar.

Em fevereiro de 2018, o Ministério do Trabalho no Brasil incluiu o lobby no cadastro oficial de ocupações. Desse modo, a função de "relações institucionais e governamentais" passou a ser oficialmente reconhecida pelo governo e é um passo em direção à regulamentação da profissão, que vem sendo discutida há cerca de trinta anos. A Associação Brasileira de Relações Institucionais 
e Governamentais (Abrig), que reúne lobistas, estima que aproximadamente quatro mil pessoas tenham esta atividade como ocupação profissional no Brasil. A regularização da profissão e a profissionalização da atividade permitem que as facetas pública e lícita do lobby passem a ter maior destaque e relevância (Santos et al., 2017).

Os grandes escândalos de corrupção que historicamente acompanharam o processo de democratização no Brasil endossam as relações promíscuas entre o setor público e o setor privado, especialmente as grandes corporações. Em seu estudo, os autores acima estão preocupados em legitimar a prática do lobbying e separar sua ação das práticas de corrupção, uma vez que as arenas em que ambas atuam são as mesmas:

O lobbying importa, mas sua importância deve ser considerada à luz de um conjunto de outras variáveis relevantes. Uma das variáveis mais importantes éa opinião pública, que, quando mobilizada, muda a estratégia de defesa de interesses e afeta as perspectivas de sucesso - negativamente, para os representantes do empresariado, e favoravelmente, para os representantes dos trabalhadores e, em menor medida, do setor público. Entender a ação dos grupos de interesse no processo político é uma questão essencial e complexa. Ninguém de bom senso estaria disposto a negar que setores econômicos e grupos mais organizados e institucionalizados da sociedade exercem influência política no processo decisório. A extensão dessa influência, no entanto, já é mais difícil de estimar com precisão, do ponto de vista acadêmico. Há quem advogue que o poder econômico captura as instituições de Estado e domina a política. [...] Há, por sua vez, quem veja de forma mais atenuada esse fenômeno e reconheça que em regimes democráticos, pelo menos naqueles com algum pluralismo, não existe tanto espaço para o monopólio do poder por um ou poucos grupos. Da mesma forma, aqui, esses não estarão isolados em seus argumentos. De uma ou de outra forma, o importante é reconhecer que o lobbying é um fenômeno onipresente em democracias, e no Brasil não é diferente. (Santos et al., 2017, p. 53)

Os autores também citam Adam Przeworski, para quem as relações entre dinheiro, política e democracia não se resumem ao problema da corrupção. O dinheiro e a influência são poderosos e afetam as decisões políticas mesmo que sejam legalmente aceitos.

\section{Estratégias do lobby alimentar}

Como todos os lobistas, aqueles que representam as companhias alimentares recebem amplo e íntimo acesso aos escritórios e funcionários federais e, além de trocas de conhecimento especializado, oferecem doações sancionadas (ou não) pelo governo federal, que podem aparecer na forma de fundos para partidos e campanhas eleitorais ou despesas administrativas indiretas para processos eleitorais (hard money), adicionadas de presentes e privilégios não contabilizados como renda e compra de influências (soft money). Além desses dois formatos, Nestle (2002) revela outra forma de relação a que chama de "porta giratória", nominação de uma troca frequente de postos de trabalho entre lobistas e parlamentares, que levanta questões sobre influências e jogos de poder indevidos sob a dinâmica de uma "dança das cadeiras". A autora relata inúmeras trocas de posições entre cargos de funcionários da indústria de alimentos e de biotecnologia alimentar, postos públicos 
de direção em agências de controle e vigilância alimentar, secretarias de agricultura, entre outros, que ilustram um incômodo dilema no campo do lobistas. A título de exemplo no Brasil, Baird (2016) destaca a posse de Jaime César de Moura Oliveira, em 2011, como presidente da Agência Nacional de Vigilância Sanitária (Anvisa). Antes de assumir o cargo, Oliveira era ex-advogado da subsidiária brasileira da Unilever.

No que concerne a uma das ações mais complexas do lobby supracitadas - o apoio financeiro à pesquisa acadêmica na área da alimentação, bem como suporte a periódicos, suplementos científicos e grupos de aconselhamento sobre nutrição e saúde, congressos e conferências -, destaca-se no Brasil a pesquisa com foco na soja (Azevedo, 2011). A autora mostra o processo de reconhecimento e avaliação da soja como "alimento saudável que previne doenças cardiovasculares" pelo Food and Drugs Administration (FDA). A agência regulatória estadunidense assumiu que o caminho para ganhar tal status foi "longo e exigente, constituindose numa detalhada revisão dos dados clínicos humanos, coletados em mais de 40 estudos científicos conduzidos por mais de 20 anos" (Zreik, 2000, p. 53).

Em 1998, a DuPont Protein Technology International (PTI)² encaminhou uma petição submetida ao FDA baseada em afirmativas de que os fito-hormônios isoflavonas ativos da soja poderiam resultar em um alimento com atividade hipocolesterolêmica (que baixa os níveis de colesterol no sangue). A petição foi endossada por uma pesquisa desenvolvida por James Anderson e colaboradores, financiada pela DuPont Protein Technologies International e publicada no prestigiado periódico científico New England Journal of Medicine. A partir desse episódio, Fallon e Enig (2000), citados por Azevedo (2011), apontam desvios ocorridos nesse caminho "longo e exigente". Depois desse pedido da DuPontPTI, houve uma manifestação contrária à sua aprovação, a partir de pesquisas de especialistas americanos indicando a toxicidade das isoflavonas, bem como de um relatório final do governo britânico ${ }^{3}$ que mostrava efeitos colaterais de sua ação estrogênica. Após esse processo, a FDA fez uma mudança abrupta de direção e reescreveu a petição da DuPont PTI. O órgão federal removeu quaisquer referências a fito-hormônios e substituiu o parecer com mesmo apelo para proteína de soja. Um movimento completamente contrário às regulamentações do órgão federal, uma vez que a FDA está autorizada a emitir pareceres somente sobre as substâncias apresentadas pela petição. Mesmo com a troca para a proteína isolada de soja, o órgão regulador foi forçado a rever as preocupações de cientistas quanto aos efeitos de outras substâncias encontradas na soja. Uma das mais veementes contestações veio de pesquisadores públicos ligados ao National Center for Toxicological Research ${ }^{4}$, centro de pesquisa toxicológica do próprio FDA, que questionavam o método utilizado na pesquisa e pediam rótulos de advertência nos produtos à base

\footnotetext{
2 A DuPont Protein Technologies International Inc., localizada em St. Louis, EUA, é uma marketer de proteína de soja e ingredientes à base de fibras. As empresas norte-americanas Solae, Suprem e Basis são trademarkers da Protein Technology International Inc 3 Referência ao relatório IEH, Assessment on Phytoestrogens in the Human Diet. Final Report to the Ministery of Agriculture, Fisheries and Food, UK, de novembro de 1997, p. 11 (Azevedo, 2011).

4 Menção ao documento de Daniel Sheegan e Daniel Doerge, Letter to Dockets Management Branch (HFA-305), de 18 de fevereiro de 1999 (Azevedo, 2011).
} 
de proteína isolada de soja. Entretanto, tais apelos foram rejeitados como injustificados e todos os produtos à base de soja industrializados (que perfazem 60\% dos alimentos ultra-processados nos Estados Unidos) ganharam o status de "heal thy heart food", algo como comida saudável para o coração.

No âmbito das pesquisas para liberação dos agrotóxicos, a problemática continua atualmente com os mesmos atores. A Internacional Life Science Institute (ILSI) é um grupo de lobby com escritórios em todo o mundo, liderado e financiado por muitas multinacionais de produtos químicos e alimentos, da Monsanto à Coca-Cola e ao McDonald's. Para liberar o glifosato na Europa, como um "pesticida alimentar", sem risco cancerígeno, a JMPR (Joint OMS/FAO sobre Resíduos de Pesticidas) utilizou um estudo conduzido pelo professor Alan Boobis, do Imperial College do Reino Unido, que também é vice-presidente do ILSI na Europa.

A Agência Europeia de Segurança Alimentar (EFSA) também não escapa das influências das indústrias agroalimentares. Uma denúncia publicada em 2017 pelo Corporate Europe Observatory $(C E O)^{5}$ mostra que quase metade dos especialistas da EFSA, incluindo cargos de chefia, apresenta conflito de interesses devido aos laços financeiros com indústrias agroalimentares. A análise foi baseada em auto-declaração de interesses apresentada pelos próprios componentes. Os critérios utilizados para essa análise foram o financiamento de pesquisas realizadas pelos especialistas e suas afiliações com organizações financiadas pela indústria. Segundo o relatório, "a independência não parece ter sido um critério ao decidir se vai nomear ex-especialistas, embora muitas preocupações tenham sido levantadas por ONGs, deputados do Parlamento Europeu e pela mídia". A arena de conflitos de interesse da EFSA veio à tona em 2013, com a publicação do relatório "Unhappy meals" ou "Refeições infelizes" ", de autoria do jornalista Stéphane Horel em parceria com a CEO. As críticas à EFSA endossam que a instituição foi criada para proteger a saúde e o meio ambiente e que seus padrões precisam de melhorias para encarar a influência do setor agroalimentar, sem usar a ciência como um serviço para promover seus próprios interesses.

David Michaels já questionou "se é perigoso confiar em cientistas com conflitos financeiros de interesse para interpretar dados brutos, por que devemos depender desses cientistas para fornecer conselhos às agências reguladoras?" (2008, p. 56).

Nestle (2002) aponta outros entrelaçamentos de poder que envolvem universidades e associações de controle e estudo de diferentes enfermidades (como American Heart Association; American Dietetic Association etc.) e variadas empresas, além de mencionar o apoio financeiro de importantes periódicos norte-americanos - como o Journal of Nutrition e o American Journal of Clinical Nutrition - por parte de indústrias e associações como Coca-Cola, Gerber, Nestlé, Monsanto, Roche Vitamins, The Sugar Association, Slim Fast Foods, entre outras. Entre os grupos e associações de renome que promovem a nutrição e a saúde, a autora cita a American Cancer Society, American

5 OCEO é um grupo de pesquisa sem fins lucrativos cujo objetivo declarado é expor quaisquer efeitos do lobby corporativo na formulação de políticas da União Europeia. Mais informações no site: <https://corporateeurope.org/pressreleases/2017/06/nearly-half-experts-europeanfood-safety-authority-have-financial-conflicts>. Acesso em: 11 dez. 2018.

6 Relatório disponível em: <https://corporateeurope.org/sites/default/files/attachments/unhappy_meal_report_23_10_2013.pdf>. Acesso em: 12 dez. 2018. 
College of Nutrition, American Council on Science and Health e American Society for Clinical Nutrition, apoiadas por empresas diversas como Dairy Council, Novartis, Mead Johnson, Coca-Cola, Nestlé USA e Kraft Foods (Philip Morris). Para a nutricionista, nessa trama de relações fica difícil determinar onde a prática da ciência transforma-se em propaganda ou business.

Por outro lado, sabe-se que é muito oneroso produzir ciência sem financiamento. A edição de periódicos é cara; produzir estudos requer patrocínio; congressos e simpósios exigem verbas e parcerias para sua viabilização; e as universidades não conseguem manter laboratórios e materiais de pesquisa e extensão.

A própria ciência tem aberto espaço para estudos que analisam essa problemática ou sinalizam problemas que surgem a partir dessas parcerias. Variados estudos citados por Nestle (2002) destacam que 30\% de membros de universidades aceitam financiamento de indústrias; $34 \%$ dos autores principais de 800 artigos científicos na área de biologia molecular e medicina estão envolvidos com patentes e consultorias de comitês ou estão envolvidos em companhias que podem se beneficiar com a pesquisa desenvolvida. A pesquisa britânica citada por Cannon (1987) constatou que, entre 246 membros de comitês nacionais em nutrição e políticas de alimentação, 158 são consultores ou recebem financiamentos de empresas alimentares.

No âmbito da cooptação de profissionais, geralmente líderes de áreas específicas da nutrição, Nestle (2002) mostra que esse tipo de estratégia deve ser sutil ou pouco flagrante. Por um lado, essa delicada relação não pode tornar óbvio que o especialista perdeu sua objetividade e liberdade de ação, mas é muito claro e esperado que o pesquisador esteja disponível para se posicionar favoravelmente frente aos interesses das empresas financiadoras, sem nenhuma chance de promover críticas negativas com suas pesquisas.

Azevedo (2013) questiona se a origem do financiamento influencia o conteúdo das conferências, o resultado das pesquisas e a publicação dos artigos científicos. Para a grande maioria dos cientistas e especialistas, essa pergunta é ofensiva e o respeito à ética é, em geral, evocado. $\mathrm{O}$ fato é que, se o pesquisador não aceita apoio financeiro, não realiza pesquisa ou acaba solitário; por outro lado, se aceita apoio, suas visões pessoais serão necessariamente comprometidas pelo perfil do financiador? O pesquisador pode ir contra os interesses de quem o apoia? Pode, ainda, trair suas convicções e seus valores éticos?

Para além do âmbito da ética, as questões postadas acima devem ser avaliadas no campo da saúde coletiva, no qual se percebem as repercussões sobre a saúde humana, do estímulo a orientações nutricionais equivocadas, resultado frequente dessa arena de negociações na qual, inevitavelmente, ganha o mais forte - os interesses da indústria alimentar.

Tansey e Worsley (1995), citados em Azevedo (2013), também abordam essas questões e perguntam: que tipo de pesquisa é feita no sistema agroalimentare a quem ela beneficia? E também estão preocupados com quem financia a pesquisa, quem tem propriedade sobre os resultados, onde estão as prioridades, e se precursores das novas tecnologias têm algum tipo de responsabilidade sobre seus efeitos. As forças que moldam a agenda da pesquisa e tecnologia utilizada afetam o que é descoberto, focam a direção da pesquisa e provêm produtos que servem para objetivos específicos. 
Parece muito difícil, nesse âmbito de pesquisa, que os cientistas persigam seus próprios e puros objetivos científicos. Se as áreas de pesquisa crescentes são aquelas que aumentam a rentabilidade de um produto, outra pergunta que surge é: rentabilidade de quem e como ela é definida?

O que tais questões traduzem é uma desconfiança acerca do apoio da indústria de alimentos e sua influência nos resultados de pesquisas e nas opiniões dos especialistas. Esta é uma dúvida que dificilmente encontrará sua resposta definitiva, e o quadro a seguir pode gerar mais inquietações nesse sentido. $\mathrm{O}$ quadro mostra citações literais traduzidas de investigações e a origem de seus autores, todos apoiados por empresas alimentares ou por associações e/ou conselhos de produtores de alimentos (os influentes councils e boards norte-americanos). Como já mencionado anteriormente, Nestle (2002) ressaltava em 2002 que esses dados não sugerem que a pesquisa financiada por tais atores é sempre parcial, mas sinalizam a grande probabilidade de surgirem conclusões favoráveis aos interesses comerciais dos empresários.

QUADRO 1:

Citações de estudos científicos e origens de seus autores

\begin{tabular}{|l|}
\hline $\begin{array}{l}\text { "Alta quantidade de fibras nos cereais de café da manhã podem ajudar a reduzir } \\
\text { riscos de câncer associados com a baixa ingestão de fibras." (O autor é empregado da } \\
\text { Kellogs do Reino Unido.) }\end{array}$ \\
\hline "Comer dois ovos por dia durante 12 meses resulta em um mensurado efeito \\
estatístico na diminuição do colesterol LDL [...]" (Estudo financiado em parte pelo \\
Eggs Nutrition Center.) \\
\hline $\begin{array}{l}\text { "O consumo de margarina comparado com o de manteiga diminuiu os níveis de } \\
\text { colesterol LDL na taxa de 11\% em adultos e 9\% em crianças pesquisadas." (Entre os } \\
\text { patrocinadores do estudo estão o United Soy Board Association e o National } \\
\text { Assocation of Margarine Manufactures.) }\end{array}$ \\
\hline $\begin{array}{l}\text { "Estudos científicos indicam que a prevalência de intolerância à lactose- o açúcar do } \\
\text { leite-é altamente superestimada." (Um dos autores é membro do National Dairy } \\
\text { Council.) }\end{array}$ \\
\hline $\begin{array}{l}\text { "Evidências substanciais indicam que o consumo diário maior que o das doses diárias } \\
\text { recomendadas (DDR) de cálcio, ácido fólico, vitamina E, selênio e cromo reduzem o } \\
\text { risco de certas doenças para algumas pessoas." (O autor da revisão é um cientista do } \\
\text { Council for Responsible Nutrition, associação comercial da indústria de } \\
\text { suplementos.) }\end{array}$ \\
\hline $\begin{array}{l}\text { "Existem razões para preocupações que o baixo consumo de NaCl (sal) possa levar a } \\
\text { riscos metabólicos de longo termo que ainda não foram completamente } \\
\text { identificados... Nós não temos sólida evidencia de que o baixo consumo de NaCl } \\
\text { pode prevenir ou controlar pressão alta." (O revisor foi financiado parcialmente pelo } \\
\text { The Salt Institute, uma organização comercial da indústria do sal.) }\end{array}$ \\
\hline $\begin{array}{l}\text { "Um consumo moderado de vinho ( } 2 \text { a } 5 \text { copos por dia) foi associado com uma taxa } \\
\text { parcialmente pelo The French Technical Institute of Wine.) }\end{array}$ \\
\hline
\end{tabular}

Fonte: Nestle (2002), tradução em Azevedo (2013).

Estes são dilemas de difícil abordagem, e Nestle, em 2002, também se mostrava reticente frente a tais questões. Porém, na sua última publicação, de 2018, a autora assume que o engajamento de especialistas e instituições de pesquisa com a indústria agroalimentar coloca esses profissionais nos objetivos do marketing e fomento a vendas e, frequentemente, contra as premissas da promoção da saúde coletiva. Ela defende que capturar especialistas em nutrição (e agricultura) é uma argilosa estratégia para influenciar políticas públicas e recomendações nutricionais favoráveis aos 
interesses da indústria. A nutricionista mostra que a pesquisa patrocinada por empresas promove, com frequência, o interesse do patrocinador e que muitos cientistas sobrevivem fazendo esse tipo de pesquisa para o que chamam de "clientes ou financiadores" e clama que é imperativo descolar a pesquisa de financiamento da indústria de alimentos completamente (Nestle, 2018).

O que se percebe é que ao longo dos seus anos pesquisando a temática dos lobbies alimentares e sua influência na saúde coletiva, Marion Nestle tornou-se menos condescendente do que na publicação de 2002. Questionada recentemente sobre as maiores barreiras para o progresso do movimento de alimentos saudáveis, alfineta:

Grande negócio. Grande agricultura. Comida grande. Carne grande. Essas indústrias investem muito dinheiro no tipo de comida que estão produzindo e não querem perder lucros. As empresas têm acionistas para agradar. Os produtores de carne não querem que o custo da ração suba, e eles não querem - ou não podem - pastorear o gado na grama ou fazer outras coisas que possam elevar os custos. A maneira como o nosso sistema alimentar funciona é sobre os imperativos do negócio. Estas são sobre dinheiro. Eles não são sobre saúde pública (Nestle, apud Rinker, 2018).

No Brasil, o tema dos lobbies alimentares e seus impactos à saúde coletiva ainda é pouco pesquisado, mas algumas relações endossam a problemática em maior ou menor escala. $\mathrm{O}$ que deve ser discutido em países de todo o hemisfério sul é o sistema agroalimentar que inicia com multinacionais de insumos agrícolas e pecuários e termina com a venda de produtos ultraprocessados facilmente disponíveis em todos os territórios de consumo alimentar - até aqueles em áreas mais remotas e sem acesso a nenhuma forma de segurança alimentar e nutricional -, conhecidos como desertos alimentares.

Jacobs e Richtel (2017) abordam essa parceria entre a indústria de insumos agrícolas e a de alimentos e mencionam as estratégias das multinacionais na agricultura local de países em desenvolvimento, estimulando os agricultores a trocar o cultivo de alimentos para autoconsumo por commodities, base de produtos alimentícios industrializados como milho, soja e cana-de-açúcar. Para os autores, em países como a China, a África do Sul e a Colômbia, o crescente poder das grandes empresas de alimentos também se traduz em influência política - via lobbies -, impedindo que autoridades em saúde pública consigam taxar refrigerantes, por exemplo, ou divulgar e criar leis destinadas a restringir os impactos dos alimentos processados na saúde.

O caso da Resolução 25/15 (RDC) da Agência Nacional de Vigilância Sanitária no Brasil é emblemático. Baird (2016) estudou os esquemas de lobby na regulação da publicidade de alimentos da Anvisa, mais especificamente a RDC 24/15, que regula a publicidade de bebidas com baixo teor nutricional e de alimentos considerados potencialmente nocivos à saúde, por conterem quantidades elevadas de açúcar, gordura saturada, gordura trans e sódio. $\mathrm{O}$ autor revela a intensa ação do empresariado sobre a frágil autonomia política da Anvisa e a busca incisiva de apoio de outros órgãos do Poder Executivo e do Congresso Nacional até chegar à inviabilização da aplicação da Resolução sob decisão do poder Judiciário, no âmbito da Advocacia Ceral da União. Tal resultado enfraqueceu ainda mais a agência em seu poder regulatório. 
Advogados e lobistas da indústria alimentícia conduziram uma articulada campanha com acadêmicos e especialistas financiados pela indústria, que apareceram na mídia para acusar as normas de serem economicamente desastrosas e desqualificar a influência da propaganda sobre a saúde das crianças. Especialistas escreveram artigos, sugerindo que o exercício físico e o controle mais rigoroso dos pais seriam mais eficazes do que as regulações no combate à obesidade infantil (Jacobs; Richtel, 2017).

O estudo de Baird (2016) demonstra que a estratégia de sucesso e influência dos lobbies dos grupos de interesses empresariais passa pela exploração incessante de todas as frentes (inclusive científicas) e canais políticos possíveis, aproveitando-se do acesso privilegiado facultado por seu amplo poder econômico. O autor enfatiza o lobby do empresariado como "extremamente eficaz na reestruturação das relações com a Anvisa para o futuro, o que nos remete às dificuldades de equilibrar o jogo político na democracia diante do peso incontrastável do poder econômico" (Baird, 2016, p. 88).

Outros exemplos de poderosos sistemas de lobbies no Brasil recente são a liberação dos transgênicos pela Comissão Técnica Nacional de Biossegurança (CTNBio), formada por uma potente coalisão de diversos membros de indústrias de biotecnologia, e a proibição de menção ao termo transgênicos nos rótulos dos alimentos; a flexibilização das leis do uso de agrotóxicos como a recente $\mathrm{PL}$ do veneno e a proposta de lei dos cultivares determinadas pelas empresas de insumos agrícolas; e o lobby da indústria alimentar junto ao governo, congresso e tribunais brasileiros, para barrar as estratégias da Anvisa que visam limitar as iniciativas de aprimorar a rotulagem dos alimentos no sentido de proteger o direito do consumidor à informação correta.

Em 2000, uma nova recomendação de extensão do tempo de amamentação exclusiva de quatro para seis meses foi adotada pelo Brasil, que pressionou, inclusive, a Organização Mundial da Saúde para adotar a medida. As empresas de leites "maternizados", incluindo a Nestlé, a maior empresa mundial de alimentos e bebidas, que emprega no Brasil mais de 21 mil colaboradores diretos, conseguiram barrar a política por um ano (Jacobs; Richtel, 2017).

A composição da Associação Brasileira das Indústrias da Alimentação inclui um grupo lobista cujo conselho de vice-presidentes é formado por executivos da Nestlé, da produtora de carnes Cargill e da Unilever, um poderoso conglomerado de alimentos europeu, dono de marcas como Hellmann's, óleo Mazola e Ben \& Jerry's (Jacobs; Richtel, 2017).

O Portal da Transparência consultado por Jacobs e Richtel (2017) mostra que, em 2014, as empresas alimentícias doaram quase 500 milhões de reais a membros do Congresso Nacional, três vezes mais do que em 2010. O portal revela também que mais da metade dos atuais legisladores federais do país foi eleita com doações da indústria de alimentos antes de o Supremo Tribunal Federal proibir contribuições de empresas em 2015. Em 2014, a Coca-Cola doou mais de 20 milhões de reais em contribuições de campanha e o McDonald's, cerca de 1,7 milhão de reais. Mas o maior doador para candidatos do Congresso foi a JBS, uma das maiores indústrias de alimentos do mundo, que opera no

Assim como no Brasil, foi aprovado em 2015 nos Estados Unidos um projeto de lei que impede a rotulagem de organismos geneticamente modificados (transgênicos) em nível estadual, uma decisão predominantemente partidária que envolveu 45 democratas (Evich, 2015). 
processamento de carnes e doou quase 350 milhões de reais a candidatos. Nos Estados Unidos, entre 2007 e 2014, a JBS registrou o terceiro maior gasto com atividades de lobby entre empresas do setor (7,15 milhões de dólares). A empresa concentra seus esforços em temas relacionados à importação de carnes e à contratação de mão de obra de imigrantes (Trevisan, 2017).

\section{Looby alimentar favorável aos interesses da saúde coletiva}

Artigo de Evich (2015) mostra a arena de participação dos empresários das comidas "boas e maléficas" no esquema de lobbies alimentares nos Estados Unidos. Para a jornalista, os líderes do que chama de setor de "boa comida" - leiam-se empresas voltadas para a venda de alimentos saudáveis, "naturais", livres de antibióticos, locais e orgânicos - estão crescendo exponencialmente no mercado, mas ignoram a relação com o Estado e não promovem nenhuma estratégia de lobby, ao contrário das tradicionais empresas de alimentos e bebidas, que gastaram mais de 36 milhões de dólares em lobby no ano de 2014 para impulsionar sua agenda. Sob a intensa pressão dos estudos sobre os impactos da obesidade e os alertas sobre a rotulagem de transgênicos, os gigantes de alimentos e bebidas precisam cada vez mais de Washington e investem quantias recordes na história da política americana.

Já as empresas de comida saudável realizam outras atividades de marketing e de promoção de vendas voltadas para a conscientização e a educação do consumidor. Por exemplo, em vez de financiar lobistas, a Applegate ${ }^{8}$, empresa de carnes orgânicas avaliada em 800 mil dólares, produziu um documentário que defende a limitação dos antibióticos na agricultura, realizando exibições em toda a América do Norte. Após as mostras, a empresa direcionava os espectadores a contatar os membros do Congresso para exigir banimento no uso de drogas veterinárias na pecuária. A empresa, que nunca considerou a contratação de lobistas e afirma que o crescimento das vendas ocorre apesar da ausência de práticas lobistas, também organizou uma exibição especial do filme dentro do Congresso dos Estados Unidos. Porém, diversas vozes envolvidas em ações políticas alimentares clamam pela necessidade de "mais envolvimento político" (ou seja, pagar para jogar com o mesmo nível de poderes) e menos ações a que chamam de "culturais" (educacionais ou "apolíticas" como mencionado no texto em questão) da indústria alimentar saudável, que, diga-se de passagem, não é frágil do ponto de vista econômico; algumas empresas são avaliadas em 20 milhões de dólares, como a Chipotle, e em 14 milhões de dólares, como a Whole Foods. Mas, para alguns poucos proprietários de empresas "saudáveis", somente dessa forma seria possível enfrentar efetivamente os obstáculos e desviar das ações tendenciosas das políticas de alimentação e nutrição - cujas premissas não se baseiam necessariamente nas orientações dos especialistas em saúde coletiva. No governo de Barack Obama, graças ao apoio e interesse pelo ativismo dos orgânicos da primeira dama, a indústria insurgente teve algumas conquistas políticas, como os avanços significativos na lei agrícola, que incluiu mais apoio, financiamento para pesquisas e subsídios para agricultores orgânicos (Evich, 2015). 
O que chama atenção nessa discussão, para além da naturalização dos lobbies como legítima ação política, é o estímulo para que as indústrias da "saúde" entrem no jogo para implementar uma ação "sistêmica" que endosse a já distorcida política agroalimentar dos Estados Unidos. Outra dimensão que o texto destaca é a reducionista visão do que se entende como ação política - vinculada a um espaço parlamentar formal, sem menção à arena das micropolíticas, políticas da vida, políticas do cotidiano, implícitas no ativismo alimentar e discutidas no Manifesto da comida de verdade (Azevedo, 2016).

\section{Considerações finais}

O artigo abre portas para algumas considerações. Ressalta-se primeiramente a importância de mais pesquisas acadêmicas sobre os lobbies alimentares e sua imbricada arena sociopolítica e econômica no Brasil, que tem como foco central as relações de poder.

As demandas para moralizar o campo de pesquisas incluem creditação de estudos regulatórios para apoiar a aprovação de pesticidas e outros tipos de contaminantes alimentares utilizados intencionalmente, realizada porautoridades públicas; nunca pela indústria agroalimentar. Além disso, os estudos usados para apoiar a regulação de pesticidas ou de alimentos saudáveis (ou de risco) devem ser publicados em periódicos especializados independentes. A indústria não pode influenciar ou decidir que membro do estado vai liderar a avaliação científica dos seus produtos. E, por fim, a ciência baseada em evidência deve abrir um diálogo com as ciências ambientais, humanas e sociais e incluir na arena de avaliação de riscos outros atores, não só os especialistas, mas também os leigos que têm outros tipos de saberes e percepção de riscos-igualmente legítimos em uma construção de ciência mais democrática. A saber, os ambientalistas e ativistas, os agricultores e produtores de alimentos e os consumidores.

A perspectiva do Foucault pode ajudar a complexificar o entendimento sobre o exercício de poder pulverizado entre variados agentes mencionados no texto. Tal fragmentação é central para discutir o poder, que, para Foucault (2018, p. 100), não é como algo "centralizado em um conjunto de instituições" ou em "aparelhos garantidores de sujeição dos cidadãos em um estado determinado". As premissas de Foucault sobre as relações de poder revelam os apoios correlacionados dos lobbies alimentares, a diversificação de atores e arenas de ação e a incapacidade de rastreamento das relações que ocorrem em redes aparentemente imprecisas, porém extremamente focadas:

[...] deve-se compreender o poder, primeiro, como a multiplicidade de correlações de forças imanentes ao domínio onde se exercem e constitutivas da sua organização; o jogo que, através de lutas e afrontamentos incessantes as transforma, reforça, inverte; os apoios que tais correlações de forças encontram umas nas outras, formando cadeias ou sistemas ou ao contrário, as defasagens e contradições que as isolam entre si; enfim, as estratégias em que se originam e cujo esboço geral ou cristalização institucional toma corpo nos aparelhos estatais, na formulação da lei, nas hegemonias sociais. (2018, pp. 100-101) 
O filósofo francês debate relações de poder que não existem como uma condição de "exterioridade com respeito a outros tipos de relações (processos econômicos, relações de conhecimento, relações sexuais), mas lhe são imanentes" (Foucault, 2018, p. 102). Para ele, as relações de poder não estão em posição de superestrutura, com um simples papel de proibição, ou de recondução: possuem, lá onde atuam, "um papel diretamente produtor".

Os exemplos de uso de agentes científicos para promover consumo e estratégias de propaganda do suposto alimento saudável mostram uma articulação que é promovida através da construção de discursos positivados, exatamente como define Foucault quando aborda o aspecto auspicioso do poder:

É preciso parar de sempre descrever os efeitos do poder em termos negativos: ele "exclui", ele "reprime", ele "recalca", ele "censura", ele "abstrai", ele "mascara", ele "esconde". De fato, o poder produz; ele produz o real; produz domínios de objetos e rituais de verdade. (Foucault, 2001, p. 161; grifo nosso)

O jogo de poderes recebe uma outra conotação na vida moderna, não mais repressiva, de um poder centralizado, mas uma relação produtiva (como a propaganda veiculada atualmente pela emissora Clobo, no país, para apresentar a faceta benéfica do agronegócio: "o agro é pop"). Essa é uma grande contribuição de Foucault: o ensinamento de que estamos sendo induzidos por mecanismos outros, que pertencem ao campo da positividade, e, assim, se tornam muito mais difíceis de combater. No caso dos lobbies alimentares, formou-se um imbricado e intangível conjunto de legitimidades que atravessa o corpo social sem reprimi-lo; ao contrário, a prática é insistentemente ligada à noção de democracia, ao envolvimento político, à defesa de representatividades - a tal ponto de taxar de apolítica a indústria de alimentos saudáveis que não tem a prática de lobby como estratégia de reconhecimento.

Outras relações de positividade ligadas aos lobbies alimentares são o apoio à ciência e o endosso dos discursos dos especialistas. A construção coletiva de um poder-saber quando aplicada sobre o corpo torna-se uma estratégia emblemática de "biopoder" foucaultiano, uma sujeição de "corpos dóceis" exercida desde o século XVIII sob a condição moderna, na qual, pela primeira vez na história, o biológico reflete e apoia um sistema político:

Esse biopoder, sem a menor dúvida, foi o elemento indispensável ao capitalismo, que só pode ser garantido à custa da inserção controladora dos corpos no aparelho de produção e por meio de um ajustamento dos fenômenos de população aos processos econômicos [...] o investimento sobre o corpo vivo, sua valorização e a gestão distribuída de suas forças foram indispensáveis naquele (e ainda o são nesse) momento. (Foucault, 2018, p. 152; grifo nosso)

Junto à positividade, outra dimensão do poder analisada por Foucaultésua imaterialidade, que o coloca precisamente em lugar nenhum, em nenhuma classe específica, em nenhum grupo exclusivo. O poder foucaultiano aparece intoleravelmente presente sem ser visível; é inadquirível, impalpável e impossível de compartilhar, apesar de muitos o exercerem. Não é dicotômico ou 
binário, mas é plural e inconclusivo. Sob essa ótica, não é possível perceber exatamente quem domina ou quem é dominado no contexto político do lobby alimentar. Quem é o principal agente do lobby alimentar? A indústria? A ciência? Os especialistas? Os lobistas? Os políticos? É justamente a incapacidade de definir ética ou juridicamente o papel do lobista ou do especialista que dá o parecer favorável ao alimento produzido pela indústria que o patrocina e que legitima socialmente tais atores e tais ações. Parafraseando David Michaels (2008) no título de seu livro: "a dúvida é o produto deles".

Tal abordagem complexifica muito o contexto no qual o conceito de alimento saudável é construído, ingenuamente relacionado ao âmbito de especialistas da área da saúde. Na realidade, sob o espectro dos lobbies alimentares, questionar se um alimento é saudável torna-se pouco relevante, e a questão deve ser substituída por outra: como se estabelecem as relações de poder nas variadas arenas político-sociais que influenciam a construção do conceito de alimento saudável?

\section{Referências}

ARAÚjO, Anderson Luiz Alves. A necessidade de regulamentação do lobby no Brasil e a experiência americana. Jota, São Paulo, 19 jul. 2018. Disponível em: <https://www.jota.info/coberturasespeciais/as-claras/lobby-brasil-estados-unidos-19072018>. Acesso em: 5 out. 2018.

AZEVEDO, Elaine de. Riscos e controvérsias na construção do conceito de alimento saudável: o caso da soja. Revista de Saúde Pública, São Paulo, v. 45, n 4, pp. 781-8, 2011.

A ciência e os riscos ambientais vinculados ao sistema agroalimentar Moderno. Caderno Eletrônico de Ciências Sociais, UFES, Vitória, v. 1, n. 1, pp. 18-40, 2013.

Manifesto da comida de verdade. Brasília: s.n., 2016. Disponível em: <https://drive.google.com/ file/d/oB6TZXfrmlTeNbXd1WTZRV3hiR2s/view>. Acesso em: 9 out 2018.

BAIRD, Marcello Fragano. O lobby na regulação da publicidade de alimentos da Agência Nacional de Vigilância Sanitária. Revista Sociologia e Política, Curitiba, v. 24, n. 57, pp. 67-91, mar. 2016.

CANNON, Geoffrey. The politics of food. Londres: Century, 1987.

EVICH, Helena Bottemiller. "Cood Food" vs. "Big Food": food and beverage powerhouses spend big money on lobbying. Companies like Chipotle and Whole Foods don't. Politico, Washington, 8 jan. 2015. Disponível em: <https://www.politico.com/story/2015/08/good-foodcompanies-leave-lobbying-off-the-menu-120878>. Acesso em: 3 out. 2018.

FALLON, Sally; ENIG, Mary G. Tragedy and hope: the third International Soy Symposium. Nexus Mag, Maleny, v. 7, n. 3, p. 66-71, 2000.

FOUCAULT, Michel. História da sexualidade: a vontade de saber. Rio de Janeiro/São Paulo: Paze Terra, 2018. . Vigiar e punir. Petrópolis: Editora Vozes, 2001.

GONÇALVES, Maria Cecília Nunes. Regulamentação do lobby no Congresso Nacional brasileiro: o estudo comparado do modelo norte-americano. Monografia (Curso de Especialização) - Centro de Formação, Treinamento e Aperfeiçoamento da Câmara dos Deputados (Cefor). Brasília, 2012.

JACOBS, Andrew; RICHTEL, Matt. Como a grande indústria viciou o Brasil em junk food. The New York 
Times, Nova York, 16 set. 2017. Disponível em: <https://www.nytimes.com/2017/09/16/ health/brasil-junk-food.html>. Acesso em: 2 set. 2018.

MICHAELS, David. Doubt is their product: how industry's assault on science threatens your health. Oxford: Oxford University Press, 2008.

NESTLE, Marion. Food lobbies, the food pyramid, and U.S. nutrition policy. International Journal of Health Services, v. 23, n. 3, pp. 483-96, 1993.

. Food politics. Berkeley/Los Angeles/Londres: University of California Press, 2002.

. Unsavory truth: how food companies skew the science of what we eat. Nova York: Basic Books, 2018.

RINKER, Brian. Can our food system be fixed? Wellness, Berkeley, 16 mar. 2018. Disponível em: <http://www.berkeleywellness.com/healthy-eating/food/article/can-our-food-system-befixed>. Acesso em: 30 set. 2018.

SANTOS, Manoel Leonardo et al. Lobbying no Brasil: profissionalização, estratégias e influência. Texto para discussão (Instituto de Pesquisa Econômica Aplicada). Brasília/Rio de Janeiro: Ipea, 2017.

TREVISAN, Claudia. Nos Estados Unidos, leis restringem lobby da]BS. O Estado de S. Paulo, São Paulo, 2 jul. 2017. Disponível em: <http://economia.estadao.com.br/noticias/geral,nos-estadosunidos-leis-restringem-lobby-da-jbs,70001873414>.Acesso em 4 out. 2018.

ZREIK, M. The great soy protein awakening. Total Health, v. 32, n. 1, pp. 52-54, 2000. 